\title{
UNEMPLOYMENT AND GDP RELATIONSHIP ANALYSIS IN THE VISEGRAD FOUR COUNTRIES
}

Ladislav MURA, PhD.

Faculty of Economics and Business, Pan-European University, Bratislava, Slovakia e-mail: ladislav.mura@gmail.com

Tibor ZSIGMOND

Faculty of Economics and Informatics, J. Selye University, Komárno, Slovakia.

e-mail: zsigmondt@ujs.sk

Adam KOVÁCS

Faculty of Economics and Informatics, J. Selye University, Komárno, Slovakia. e-mail:119725@student.ujs.sk

\section{Éva BALOGHOVÁ}

Faculty of Economics and Informatics, J. Selye University, Komárno, Slovakia. e-mail:119582@student.ujs.sk

\begin{abstract}
Unemployment rate is one of the most important macroeconomic indicators. The change of the unemployment rate is highly correlated with the phase of the economic cycle. The economic growth has positive impact on employment issues, while negative growth will result in increasing unemployment. In terms of the future economic outlook, we find it important to analyse the development of the unemployment rate. This study is addressing the analysis of unemployment rate in the V4 countries of the Central European region. It is focusing on examining the relationship between the economic cycle and the long-term unemployment rate in the region. We targeted to examine the productive age group of the population (20-64 years). This group has the greatest influence on development of the employment trends. We applied the method of regression analysis and descriptive statistics. We used Eurostat as a data source. Our research has shown that there is no close relationship between the real GDP and the unemployment rate.
\end{abstract}

Keywords: unemployment rate, unemployment trends, labour market trends, employee, Visegrad Four countries

\section{Introduction}

The development of unemployment rate is a significant factor when analysing the economy. The indicators related to unemployment forecast the development of the economy in the 
examined territory. These indicators will determine whether the economy is going through a better or worse period.

Unemployment is a changing phenomenon, so certain time intervals have to be examined to assess the long-term consequences. Our study examines the period between 2008 and 2019, as 2008 is indicated as being the start of the worldwide economic downturn. The economic crisis of 2008 is considered to be the second biggest crises since the big economic crisis of 1929-1933. Data collection to our research finished in 2019. According to Paweta (2018), the financial crisis of 2008 had impact on V4 countries only several years after the crisis started. The impact of the economic crisis has weakened since 2019, and the economy has bounced back on the track it was before the crisis, even surpassed the economic activity before 2018.

The current research focuses on the examination of Visegrad Four countries in terms of unemployment. These countries are situated close to each other geographically. As a result of „,coexistence”, not only geographical, but also cultural similarities can be observed. Several historical events had taken place in their territories. Among these can be mentioned the WW II, followed by the era of socialism. The socialist era came to an end in 1989 with the revolutionary wave in the late 1980s and early 1990s. It resulted in the end of communist rule in Central and Eastern Europe and beyond, and the countries of Visegrad 4 started their parallel development. Since the Visegrad Four are also closely linked by the common past, it was relevant when the research started. The common past and history dates back to the personal union between the Kingdom of Hungary and the kingdom of Poland (1370-1384; 1440-1444), and the personal union between the Hungarians and the Czech (1305, 1419-1439, 1453-1457 and 1490-1516). These unions had impact on the surrounding countries, as well as significant was the impact of the Czechoslovak Republic (1918-1939 and 1945-1992). It is also important to mention the period between 1867 and 1918, the period of the Dual Monarchy. In the light of these historical facts we assume that common features and co-operation in field of the economy can also be detected nowadays. In terms of economic development the Visegrad Four countries are observed as a single region.

\section{Theoretical background}

The development of the world economy is influenced by a set of factors in a dynamically changing environment. According to Zeibote, et al. (2019), globalization as the most significant 
phenomenon has an impact not only on the economic competitiveness but also on regional development. The effects of globalization differ in the selected regions depending on the degree of their economic development. Although globalization has the largest impact on the functioning of the business sector, the effects of it are widespread and shape the socio-economic condition of the whole country. The fact, that the regional disparities are influenced by macroeconomic and microeconomic factors is pointed out by Lazíková et al (2018). The economic performance, GDP and the unemployment rate are those macroeconomic factors that influence the regional development (Koišová and Havierniková, 2016; Vigliarolo, 2020). Kováčik and Mariš (2014) support these findings in their earlier work and provide detailed analysis of the impact of unemployment on the regional structure of the economy. Unemployment is considered by the authors to be one of the country's most serious economic problem, as it affects the overall workingage population and the social spheres. The most serious problem in this area is the structural unemployment of older people and the youth.

According to Nielsen et al. (2015), Mügge (2016), Wang and Le (2018), unemployment ranks among the leading macroeconomic indicators, significantly affecting the economic growth, which became a discussed issue among the experts. The problem of unemployment affects the vast majority of population as it determines the employment rate of citizens in a particular country. There are many determinants affecting the development of unemployment. This study will address several of them. The regions mostly affected by unemployment are those, which were not a magnet for large enterprises, surrounded by SMEs, which can ensure employment of sufficient number of people (Lorincova, Potkány, 2016; Žul'ová, Kundrát, 2020). The countries of the European Union and the countries of Visegrad Four (V4) are marked by significant regional disparities in the field of unemployment.

As reported by Mura et al. (2018) or Srovnalíková, Havierniková, Guščinskiene (2018), monitoring the unemployment is a prerequisite for sustainable development in the EU regions, while the role of the state is to manage the unemployment rate through introduction of government measures. Promoting employment is one of the crucially important policy objectives of the state, as it is closely linked to the economic growth (Hedvicakova et al. 2018; Prasetyo and Kistanti, 2020.). It can effectively reduce the economic and social inequality. These indicators are essential in terms of managing the country's economy, but they are also the starting point for management 
of business activities. Forecasting the development of unemployment rate is of great importance in macroeconomic modelling (Čabla - Malá, 2017; Salama, Oláh, 2019; Kubák, et al., 2015).

The importance of research in the field of unemployment was emphasized by Čadil et al (2011), as unemployment in terms of public finances represents a significant cost item. Unemployment is a phenomenon characterized by serious socio-economic consequences not only for the unemployed, but also for their close environment and the whole society. The authors also reflect to the problem of unemployment that needs to be addressed comprehensively, as it affects several areas of the country's economy. It reduces the purchasing power of the population, resulting in decreasing sales of businesses, and lower amount of tax paid to the state budget.

The research of unemployment with a focus on selected Central European countries was also addressed by Xie et al. (2018). Our study is focusing on a narrow segment of Central European states, the Visegrad Four (V4) countries. The analysis performed by the authors lead them to conclusion that unemployment shocks are present only in two of the examined V4 countries, Hungary and Romania. These conclusions serve as an important basis for the government implementing economic, fiscal and monetary policy.

Since our article examines unemployment in the Central European countries with a focus on Visegrad Four countries, we will address our attention to the analysis of scientific literature related to the examined region. Tvrdoň (2013), Volek, et al. (2014), Megyesiová and Hajduová (2012), Mursa et al. (2018), Peráček et al. (2019), Tatarzak and Boichuk (2018) dealt with the issue of employment in individual sub-regions of the Visegrad Four countries. The authors primarily addressed the classical problems of unemployment, resp. employment. Scientifically interesting is the impact of increasing labour productivity, and the development of Industry 4.0, which will significantly affect the employment. Automation and robotics introduced in businesses are perceived positively, as they are decreasing the cost of employment and increase the production process. However, it is not good news in macroeconomic terms, because people becoming unemployed will become a high burden for the state budget. The government should allocate further costs to solve this problem.

The latest research results come from Kádár (2017), Koišová, et al. (2018) or Čulková, Janošková, Csikósová (2018). The authors above examined the relationship between the employment and the economic growth; education and the labour market, as well as subsequently analysed the development of labour market in the V4 countries. Industry 4.0 was addressed by 
Volek and Novotná (2017), who emphasize the impact of industrial society on the economy and the labour market.

According to the research conducted, all current trends have an impact on development of the macroeconomic indicators of individual countries. Therefore, Zieliński (2015) highlights that employment policy in V4 countries must be an integral part of the macroeconomic policy management. In addition to tools applied, it is necessary to look for new ways and opportunities employing people, especially in border regions.

The research results of Poór et al. (2017) also point to this fact. The authors focused on the evaluation of atypical forms of employment in the border regions of two V4 countries, Hungary and Slovakia. They came to conclusion that it is necessary to increase the mobility of the labour force in order to provide flexible response to the regional labour market needs. Widespread application of flexible forms of employment will be one of the options reducing unemployment as an appropriate respond on current trends in the economy (Kaźmierczyk and Chinalska, 2018). These research results are supported by findings of Korcsmáros (2018), conducting a survey in the border region area. The findings of Kovács et al. (2018) highlight that motivational incentives serve to motivate the redistribution of workforce to regions with lack of qualified workforce. According to Makedon et al (2019), Lorincová, et al. (2018), Vetráková, et al. (2018), Ližbetinová and Hitka (2016), the sustainable development requires to pay attention on the management of human resources. Although the V4 countries are geographically close to each other, there are some cultural and other differences between them. These differences require a differentiated approach when employing people at different jobs (Lazányi, et al., 2017). According to Rainsford, et al. (2019), creating appropriate working conditions is one of the preconditions for effective absorption of the unemployed. 4. Chehabeddine and Tvaronavičienè (2020) also pointed out the differentiated conditions in regional employment policy and the regional management of human resources. According to authors, there is a significant difference between the innovative and classical economies, since innovation is driven by new ideas and application of methods that naturally attract the workforce and contribute to reducing the unemployment. Motivational tools applied in selected areas of the economic sector were also addressed by Karácsony (2017). Further authors, Ližbetinová (2018) or Nosková with Peráček (2019) focused on the importance of motivation and employment in the public and private sector. The results of their findings show that not all the methods and approaches can be applied universally, but the specificities of a particular 
region, company or organization need to be taken into account. Bencsik, et al. (2017) also emphasized that the issue of employing people has to be approached differently. Their research findings can be supplemented by the results of further authors (Csehné Papp et al., 2017), who warn the attention on increasing differences on the labour market, which require a specific approach of human resource management represented by different generations.

\section{Material and Methods}

The main aim of our study is to address the development of unemployment in the Visegrad Four (V4) countries. We examined the data of the past twelve years, the period of 2008-2020. The research started in 2008, when the global financial crisis started, having significant impact on the labour market conditions, including the development of the unemployment rate. Our research was completed in the second half of 2020. The examined 12-years period provides a transparent picture of the effects of the crisis and the slowly stabilizing period. Our study focuses on people between the ages of 20 and 64. We compared the annual growth of real GDP with the annual rate of unemployment. The main purpose was to measure whether the change in real GDP has an impact on the unemployment rate or not. A linear regression model was used to determine the relationship between the two variables.

In order to obtain relevant research results, in addition to defined objectives and methods we used, several research questions were formulated.

1. How the unemployment rate in the examined countries is developing? What kind of trends can be observed?

2. Why the development of unemployment rate differed in Poland from the rest of the V4 countries? The Polish unemployment rate reached a peak three years later than in the rest of the V4 (2013).

3. What effect did the change in real GDP have on the development of unemployment rates?

Our data was obtained from the Eurostat database, and the calculations were performed using a statistical software. 


\section{Results and Discussion}

Table 1 shows the percentage change in GDP in V4 countries compared to previous years. We observed a significant decline in GDP after the global crisis in 2009. The GDP declined by 4.7 units in the Czech Republic, 6.7 units in Hungary and by 5.5 in Slovakia. In contrast to the V4 countries mentioned, there was a slow growth in Poland. Apparently, as the economies of the Visegrad Four countries began to show development trend and started to recover from the crisis, a steady GDP growth can be observed annually until 2018. There was a slight drop in 2019 in all of the countries in the group.

Table 1 Percentage change in GDP compared to the previous years $(\%)$

\begin{tabular}{|l|l|l|l|l|l|l|l|l|l|l|l|l|}
\hline & $\mathbf{2 0 0 8}$ & $\mathbf{2 0 0 9}$ & $\mathbf{2 0 1 0}$ & $\mathbf{2 0 1 1}$ & $\mathbf{2 0 1 2}$ & $\mathbf{2 0 1 3}$ & $\mathbf{2 0 1 4}$ & $\mathbf{2 0 1 5}$ & $\mathbf{2 0 1 6}$ & $\mathbf{2 0 1 7}$ & $\mathbf{2 0 1 8}$ & $\mathbf{2 0 1 9}$ \\
\hline $\begin{array}{l}\text { Czech } \\
\text { Republic }\end{array}$ & 2.7 & -4.7 & 2.4 & 1.8 & -0.8 & 0.0 & 2.3 & 5.4 & 2.5 & 5.2 & 3.2 & 2.3 \\
\hline Hungary & 1.1 & -6.7 & 1.1 & 1.9 & -1.4 & 1.9 & 4.2 & 3.8 & 2.1 & 4.3 & 5.4 & 4.6 \\
\hline Poland & 4.2 & 2.8 & 3.7 & 4.8 & 1.3 & 1.1 & 3.4 & 4.2 & 3.1 & 4.8 & 5.4 & 4.5 \\
\hline Slovakia & 5.6 & -5.5 & 5.9 & 2.8 & 1.9 & 0.7 & 2.6 & 4.8 & 2.1 & 3.0 & 3.8 & 2.3 \\
\hline
\end{tabular}

Source: own editing based on Eurostat database

Figure 1 shows the changes in aggregate GDP projected to the V4 countries in the period of 2008-2019. It is clear that the post-crisis period of 2008 shows the lowest point of economic activity in the examined countries (except Slovakia). The years until 2017 show a steady growth with stabilizing GDP growth. The highest growth in Hungary and Poland compared to the previous year was achieved in 2018 (5,4\% both Hungary and Poland). The highest growth in Slovakia was in 2010, while the Czech Republic reached the highest growth in 2015. 
Figure 1. Percentage change in GDP in relation to the V4 (2008-2019)

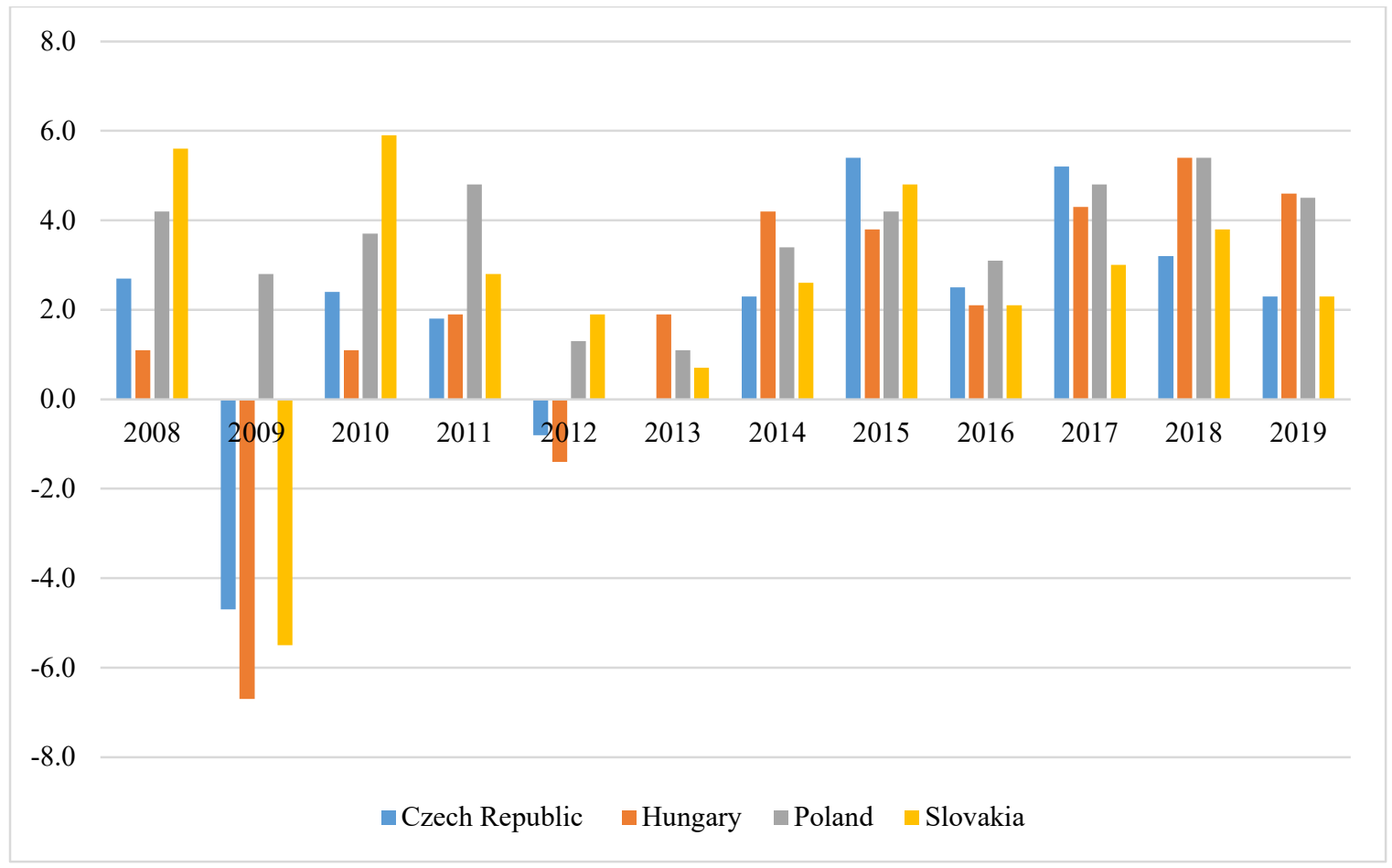

Source: own editing based on Eurostat database

As it was presented, the global economic crisis of 2008 was the most influential phenomenon at the beginning of the $21^{\text {st }}$ century. During and after the crisis, thousands of companies went bankrupt, became indebted or merged with competitors. A high increase of unemployment rate can be detected until 2010. The unemployment rate showed an increase of at least $1 \%$ in all the V4 countries. The economic growth stabilized in 2010, which had a positive impact on the unemployment rate too. The year 2011 was a turning point following the economic crisis, since the unemployment rate fell in the examined countries (except in Poland). In terms of the V4, the Czech Republic became the country with the lowest rate of unemployment, levelling at 2.0\%, while Slovakia had the highest unemployment rate of 5.6\%. in 2019. 
Table 2. The unemployment rate in V4 countries (2008-2019)

\begin{tabular}{|l|l|l|l|l|l|l|l|l|l|l|l|l|}
\hline & $\mathbf{2 0 0 8}$ & $\mathbf{2 0 0 9}$ & $\mathbf{2 0 1 0}$ & $\mathbf{2 0 1 1}$ & $\mathbf{2 0 1 2}$ & $\mathbf{2 0 1 3}$ & $\mathbf{2 0 1 4}$ & $\mathbf{2 0 1 5}$ & $\mathbf{2 0 1 6}$ & $\mathbf{2 0 1 7}$ & $\mathbf{2 0 1 8}$ & $\mathbf{2 0 1 9}$ \\
\hline $\begin{array}{l}\text { Czech } \\
\text { Republic }\end{array}$ & 4.3 & 6.5 & 7.1 & 6.5 & 6.8 & 6.8 & 6.0 & 5.0 & 3.9 & 2.8 & 2.2 & 2.0 \\
\hline Hungary & 7.7 & 9.9 & 11.1 & 11.0 & 10.9 & 10.0 & 7.6 & 6.7 & 5.0 & 4.0 & 3.6 & 3.3 \\
\hline Poland & 7.0 & 8.1 & 9.5 & 9.5 & 10 & 10.2 & 8.9 & 7.4 & 6.1 & 4.8 & 3.8 & 3.2 \\
\hline Slovakia & 9.2 & 11.7 & 14.0 & 13.2 & 13.6 & 13.9 & 12.9 & 11.3 & 9.5 & 7.9 & 6.4 & 5.6 \\
\hline
\end{tabular}

Source: own editing based on Eurostat database

The Czech Republic was the one among the Visegrad Four countries to survive the postcrisis period the smoothest way. This country had the lowest unemployment rate since the beginning of the economic crisis. At the beginning of the crisis, the unemployment rate in the country was 4.3\%. The highest value of unemployment was reached in 2010 (7,1\%). In 2012 and 2013 a slight increase in unemployment rate could be detected, which shows downward trend compared to 2014. By the end of the research period (2019), the unemployment rate dropped to $2.0 \%$.

In Hungary, the unemployment rate increased by almost two units a year within two years following the economic crisis. A slow decline could be detected from 2010 to 2013. The highest unemployment was measured in 2010, when it reached $11.1 \%$. The unemployment rate showed a downward trend from 2010 to 2019. By the end of the research period, the unemployment rate dropped to $3.3 \%$. In Hungary, the unemployment rate halved following the global economic crisis.

Poland struggled in the post-crisis period. The unemployment rate increased from 2008 to 2013. It decreased by more than $1 \%$ compared to 2014 . By the end of the research period, the unemployment rate dropped to 3.2 percentage points, which is almost half the initial rate. The unemployment rate fell to the lowest level in 2019.

Slovakia had the highest unemployment rate among the V4 countries in the examined period. At the beginning of the examined period, the unemployment rate was $9.2 \%$. The country also experienced difficult years between 2008 and 2010. The unemployment rate increased by 
$4.8 \%$ during this period. In the early $2010 \mathrm{~s}$, many people were unable to find a job within a year. This also affected the unemployment rate, which started to increase in 2011. This trend turned to decreasing rate of unemployment in 2013 , when the unemployment rate dropped by $1 \%$.

Figure 2. Distribution of unemployment in the V4 countries

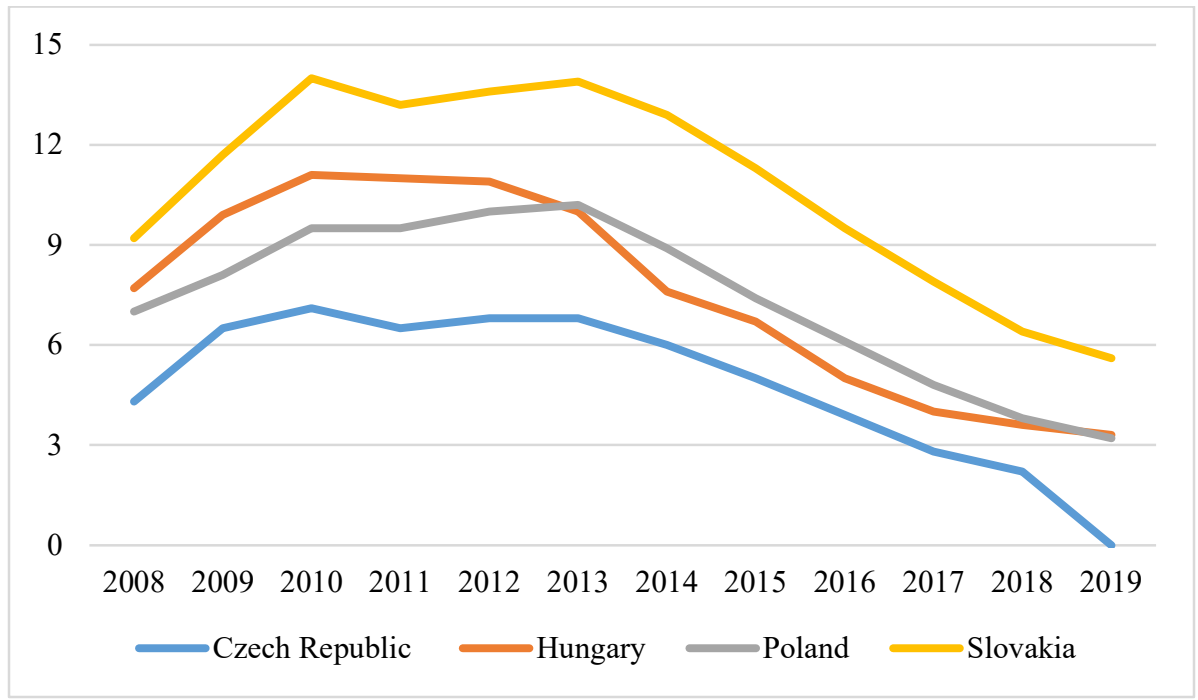

Source: own editing based on Eurostat database

The following figure shows the relationship between the unemployment rate and the real GDP in the V4 countries. There are further differences between the countries based on the figure.

Figure 3. Relationship between the unemployment rate and the real GDP in V4 countries

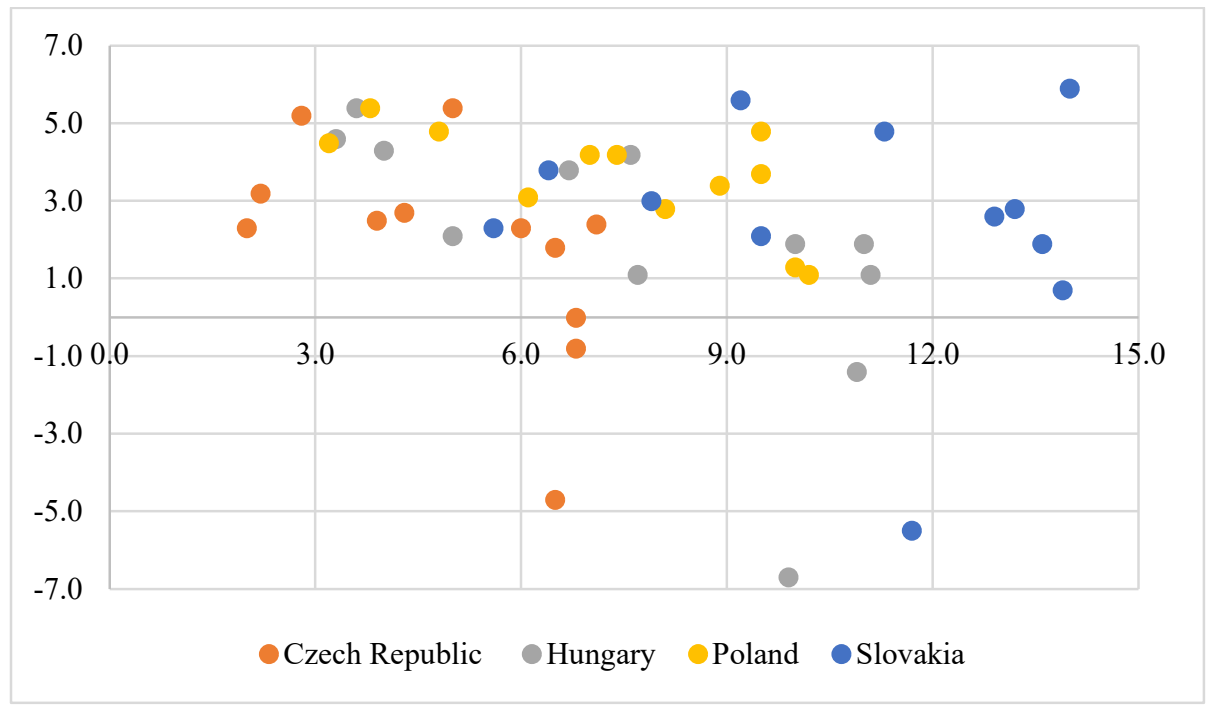

Source: own editing 
The following table shows the relationship between the unemployment rate and the development of real GDP based on a linear regression calculation.

Table 3. Linear regression between the unemployment rate and the real GDP

\begin{tabular}{|l|l|l|l|}
\hline & \multicolumn{2}{|l|}{ Regression Statistics } & Coefficients \\
\hline \multirow{2}{*}{ Czech Republic } & Multiple R & 0.532667057 & 5.649439474 \\
\cline { 2 - 4 } & R Square & 0.283734194 & -0.75948704 \\
\hline \multirow{2}{*}{ Polangary } & Multiple R & 0.636073765 & 7.118205425 \\
\cline { 2 - 4 } & R Square & 0.404589834 & -0.695137281 \\
\hline \multirow{2}{*}{ Slovakia } & Multiple R & 0.66379529 & 6.325052591 \\
\cline { 2 - 4 } & R Square & 0.440624186 & -0.368368713 \\
\hline & Multiple R & 0.124266756 & 3.826509017 \\
\cline { 2 - 4 } & R Square & 0.015442227 & -0.123205172 \\
\hline
\end{tabular}

Source: own editing

Based on the research results, it can be said that the change in real GDP has no significant impact on the unemployment rate in Slovakia. The regression value is 0.015442227 . The regression value of 0.283734194 in the Czech Republic is not convincing at all. Among the V4 countries, Hungary and Poland have closed with the highest, but not at all convincing values. It can be also said that even these values are not so high (Hungary: 0.404589834, Poland: 0.440624186). In terms of the two parameters set, we can conclude that there is no strong correlation.

\section{Conclusion}

The first part of the study introduced the concept of unemployment and the literary overview of the issue. In addition, the partial results and findings about the unemployment were presented.

The research results introduced the development of unemployment rate in the V4 countries. In order to make the data easier to understand, we presented the obtained data of unemployment rate by using tables and figures. It was followed by the examination of annual changes in real GDP in the V4 countries. The changes in real GDP were compared to the unemployment rate of each country. Linear regression was used to determine the relationship between the unemployment rate 
and the real GDP. Data were collected in a 12-years interval, reflecting the results from the period of 2008-2019.

The obtained results show a weak relationship between the examined factors. Based on this evidence, there was a weak relationship between the real GDP and the unemployment rate in the V4 countries during the examined period. Our research findings correlate with the research results of Paweta (2018), who emphasized that the crisis had impact on the economy of the V4 with a time shift. The research results show that the period following the economic crisis had influence on the economy and the labour market of the V4 countries. However, Poland is different from the rest of the countries. Both the decline in real GDP and the unemployment rate has lengthened in the Polish economy, so they experienced the fallback in smaller measure. Poland was the only European country to survive the $2008 / 2009$ crisis without recession. The main reason was the macroeconomic stability of the country.

The results indicate further research to be conducted in order to get more details about the addressed issue. In order to expand our research, the application of further indicators is required, and provide analysis in terms of age and gender distribution.

Considering the current situation, when the world is heading towards the worldwide recession as a result of pandemic COVID-19, we would like to extend our future research by examining the economic indicators of this period. The results we plan to compare to the research trends outlined in the current article. The economic crisis caused by the pandemic COVID-19 also affects the economies of the V4. The Polish economy again seems to be the most resilient among the countries of the V4. The forthcoming months and the next year will be challenging for the countries, the indicators may vary depending on the scale of the crisis.

\section{Acknowledgement}

This paper represents a partial result of the project 1/2019 - PADE-0117-2. This research was supported by the "GAAA 5-5/2020 Development of family businesses in Slovak regions" project, which has received funding from Grant Agency Academia Aurea, too. 


\section{References}

1. BENCSIK, A., JUHASZ, T., MACHOVA, R. 2017. The Problems Created by the Arrival of Generations $\mathrm{Z}$ and $\mathrm{Y}$ in the Workplace. Proceedings of the 5th International Conference of Management, Leadership and Governance (ICMLG 2017), pp. 46-53

2. ČABLA, A., MALÁ, I. 2017. Modelling of unemployment duration in the Czech Republic. Prague Economic Papers, 26 (4), pp. 438-449. doi: 10.18267/j.pep.620

3. Č́ADIL, J., PAVELKA, T., KAŇKOVÁ, E., VORLÍČEK, J. 2011. Odhad nákladů nezaměstnanosti z pohledu veřejných rozpočtů. Politická ekonomie, 59 (5), pp. 618-637. doi: $10.18267 /$ j.polek. 811

4. CHEHABEDDINE, M., TVARONAVIČIENĖ, M. 2020. Securing regional development. Insights into Regional Development 2(1), pp. 430-442. doi: 10.9770/IRD.2020.2.1(3)

5. ČULKOVÁ, K., JANOŠKOVÁ, M., CSIKÓSOVÁ, A. 2018. Factoring services in conditions of V4 countries. Polish Journal of Management Studies, 18 (2), pp. 33-45. doi: 10.17512/pjms.2018.18.2.03

6. EUROPEAN COMMISSION. 2019. Real GDP growth rate - volume. Retrieved Nov. 2, 2020 from: https://ec.europa.eu/eurostat/tgm/table.do?tab=table\&plugin=1\&language=en $\underline{\text { \&pcode }=\text { tec } 00115}$

7. EUROPEAN COMMISSION. 2019. Unemployment rate by age. Retrieved Nov. 2, 2020 from: https://ec.europa.eu/eurostat/tgm/refreshTableAction.do?tab=table \& plugin=1\& pcode $=$ tepsr_wc170\&language $=$ en

8. HEDVICAKOVA, M., SOKOLOVA, M., MOHELSKA, H. 2018. The Impact of Economic Growth on Wages and The Supply of Employee Benefits in The Czech Republic. Transformations in Business \& Economics, 17 (3), pp. 140-154

9. KÁDÁR, B. 2017. Including labour market proposals in higher education offers. Acta Oeconomica Universitatis Selye, 6 (2), pp. 89 - 100

10. KARÁCSONY, P. 2017. The Analyze of the employes motivation methods in environmentally friendly organizations. International Journal of Ecology and Development, 32 (3), pp. 119-128 
11. KAŹMIERCZYK, J., CHINALSKA, A. 2018. Flexible forms of employment, an opportunity or a curse for the modern economy? Case study: banks in Poland. Entrepreneurship and Sustainability Issues, 6 (2), pp. 782-798. doi: 10.9770/jesi.2018.6.2(21)

12. KOIŠOVÁ, E. MASÁROVÁ, J., GULLEROVÁ, M. 2018. Trends in inclusive labour market developments in the Visegrad Group. Sociálno- ekonomická revue. 01, pp. 42-52

13. KOIŠOVÁ, E., HAVIERNIKOVÁ, K. 2016. Evaluation of selected regional development indicators by means of cluster analysis. Actual problems of Economics, 184 (10), pp. 434-443

14. KOVÁCS, I. E., MÁZÁSNÉ DINNYÉS, H., MACK, Á., FEHÉR, J., POÓR, J. 2018. Flexible benefits - Cafeteria plan how the characteristics of the firms affect the system of cafeteria plans. Journal of Eastern European and Central Asian Research - JEECAR, 5 (1), pp. 120. doi: 10.15549/jeecar.v5i1.190

15. KOVÁČIK, M., MARIŠ, M. 2014. Vertical unemployment of citizens in regional structure of Slovakia. Acta Oeconomica Universitatis Selye, 3 (2), pp. 78 - 87

16. KUBÁK, M., BOSÁKOVÁ, L., FISAR, M., HAJDUOVA, Z., TIMUROVA, E. 2015. Dependence of Unemployment Change on Selected Economic Factors: Panel Data Evidence. Proceedings of the 19th International conference: current trends in public sector research, pp. $21-28$

17. LAZÁNYI, K., HOLICZA, P., BAIMAKOVA, K. 2017. Different Cultures Different People. Exploring the Influence of Personal Values and Cultures in the Workplace. Advances in Human Resources Management and Organizational Development Book Series, pp. $183-200$

18. LAZIKOVA, J., BANDLEROVA, A., ROHACIKOVA, O., SCHWARCZ, P., RUMANOVSKA, L. 2018. Regional Disparities of Small and Medium Enterprises in Slovakia. Acta Polytechnica Hungarica, 15 (8), pp. 227-246. doi: 10.12700/APH.15.8.2018.8.12

19. LIŽBETINOVÁ, L., HITKA, M. 2016. Selection of most suitable candidates for the talent pool in a furniture manufacturing company,Izbor najtalentiranijih kandidata u tvrtki za proizvodnju namještaja. Drvna Industrija, 67(4), 333-340. doi:10.5552/drind.2016.1601

20. LIŽBETINOVÁ, L. 2018. Satisfaction with the motivational level of Czech employees. Proceedings of the 31st International Business Information Management Association 
Conference, IBIMA 2018: Innovation Management and Education Excellence through Vision 2020, 3859-3865

21. LORINCOVÁ, S., HITKA, M., ŠTARCHOŇ, P., STACHOVÁ, K. 2018. Strategic instrument for sustainability of human resource management in small and medium-sized enterprises using management data. Sustainability (Switzerland), 10(10). doi: $10.3390 / \mathrm{su} 10103687$

22. LORINCOVA, S., POTKÁNY, M. 2016. The proposal of innovation support in small and medium-sized enterprises. Production Management and Engineering Sciences Scientific Publication of the International Conference on Engineering Science and Production Management, ESPM, 157-162

23. MAKEDON, V., HETMAN, O., YEMCHUK, L., PARANYTSIA, N., PETROVSKA, S. 2019. Human resource management for secure and sustainable development. Journal of Security and Sustainability Issues, 8 (3), pp. 345-354. doi: 10.9770/jssi.2019.8.3(5)

24. MEGYESIOVÁ, S., HAJDUOVÁ, Z. 2012. Demographic Challenges Across the European Union Member States. Workplace Health \& Safety, 60 (7), pp. 321-326

25. MÜGGE, D. 2016. Studying Macroeconomic Indicators as Powerful Ideas. Journal of European Public Policy 23 (3), pp. 410-427. doi: 10.1080/13501763.2015.1115537

26. MURSA, GC., IACOBUTA, AO., SOCOLIUC, OR., CLIPA, RI., BUTISEACA, A. 2018. Youth Unemployment Among EU Countries - A Challenge for Sustainable Growth and Social Cohesion. Transformations in Business \& Economics, 17 (2B), pp. 701-720

27. NIELSEN K. J., LANDER F., LAURITSEN J. M. 2015. The relationship between macroeconomic and industry-specific business cycle indicators and work-related injuries among Danish construction workers. Occupational and Environmental Medicine, 72 (4), pp. 271-276. doi: 10.1136/oemed-2014-102290

28. NOSKOVÁ, M., PERÁČEK, T. 2019. Termination of employment in the Slovak Republic as a key issue of HR Management. Central European Journal of Labour Law and Personnel Management, 2 (2), pp. 44-59. doi: 10.33382/cejllpm.2019.03.04

29. PAWETA, B. 2018. Impact of the Global Financial Crisis on the Business Cycle in the Visegrad Group. Entrepreneurial Business and Economics Review, 6 (3), pp. 43-58. doi: 10.15678/EBER.2018.060303 
30. PERÁČEK, T., MUCHA, B., BRESTOVANSKÁ, P. 2019. Comparative analysis of Slovak and Czech constitutional law on favorable environment. International Multidisciplinary Scientific GeoConference Surveying Geology and Mining Ecology Management, SGEM. 19 (5.4), pp. 427-433

31. POÓR, J., VINOGRADOV, S., GÁBRIELNÉ TÖZSÉR, GY., ANTALIK, I., HORBULÁK, ZS., JUHÁSZ, T., KOVÁCS, I. E., NÉMETHY, K., MACHOVÁ, R. 2017. Atypical Forms of Employment on Hungarian-Slovakian Border Areas in Light of Empirical Researches. Acta Polytechnica Hungarica, 14 (7), pp. 123-141. doi: 10.12700/APH.14.7.2017.7.8

32. PRASETYO, P. E., KISTANTI, N. R. 2020. Human capital, institutional economics and entrepreneurship as a driver for quality \& sustainable economic growth, Entrepreneurship and Sustainability Issues, 7(4), pp. 2575-2589. doi:10.9770/jesi.2020.7.4(1)

33. RAINSFORD, E, MALONEY, W. A., POPA, S. A. 2019. The Effect of Unemployment and Low-Quality Work Conditions on Work Values: Exploring the Experiences of Young Europeans. The ANNALS of the American Academy of Political and Social Science, 682 (1), pp. 172-185

34. SALAMA, A., OLÁH, J. 2019. Key factors affecting unemployment in the Arab world. Central European Journal of Labour Law and Personnel Management, 2 (2), pp. 60-72. doi: 10.33382/cejllpm.2019.03.05

35. SROVNALÍKOVÁ, P., HAVIERNIKOVÁ, K., GUŠČINSKIENE， J. 2018. Assessment of reasons for being engaged in clusters in terms of sustainable development. Journal of Security and Sustainability Issues, 8(1), pp. 103-112. doi: 10.9770/jssi.2018.8.1(9)

36. TATARCZAK, A., BOICHUK, O. 2018. The multivariate techniques in evaluation of unemployment analysis of Polish regions. Oeconomia Copernicana, 9 (3), pp. 361-380. doi: 10.24136/oc. 2018.018

37. TVRDON, M. 2013. The monthly unemployment rate in regions: empirical evidence from the Visegrad Group countries. 16th International Colloquium on Regional Sciences, pp. $79-85$

38. VETRÁKOVÁ, M., HITKA, M., POTKÁNY, M., LORINCOVÁ, S., SMEREK, L. 2018. Corporate sustainability in the process of employee recruitment through social networks in conditions of Slovak small and medium enterprises. Sustainability (Switzerland), 10(5). doi: $10.3390 / \mathrm{su} 10051670$ 
39. VIGLIAROLO, F. 2020. Economic phenomenology: fundamentals, principles and definition. Insights into Regional Development 2(1), pp. 418-429. doi: 10.9770/IRD.2020.2.1(2)

40. VOLEK, T., NOVOTNA, M. 2017. Labour Market in the Context of Industry 4.0. 11th International Days of Statistics and Economics, pp. 1790-1799

41. VOLEK, T., NOVOTNA, M., RAUCH, M. 2014. Factors Influencing Changes in Labor Productivity. Hradecké Ekonomické Dny 2014: Ekonomický rozvoj a management regionu, Issue III, pp. 426-432

42. WANG, C. N., LE A. L., 2018. Measuring the Macroeconomic Performance among Developed Countries and Asian Developing Countries: Past, Present, and Future. Sustainability, 10 (10), pp. 1-18. doi: 10.3390/su10103664

43. XIE, H., CHANG, TY., GRIGORESCU, A., HUNG, K. 2018. Revisit Hysteresis Unemployment in Eastern European Countries using Quantile Regression. Ekonomicky Casopis, 66 (5), pp. 522-537

44. ZEIBOTE, Z., VOLKOVA, T., TODOROV, K. 2019. The impact of globalization on regional development and competitiveness: cases of selected regions. Insights into Regional Development, 1 (1), pp. 33-47. doi: 10.9770/ird.2019.1.1(3)

45. ZIELIŃSKI, M. 2015. Unemployment and labor market policy in Visegrad Group countries. Equilibrium. Quarterly Journal of Economics and Economic Policy, 10 (3), pp, $185-$ 201. doi: 10.12775/EQUIL.2015.032

46. ŽULOVÁ, J., KUNDRÁT, I. 2020. Service of documents in employment relationships during the employee quarantine. Central European Journal of Labor Law and Personnel Management, 3 (1), 74-84. doi: 10.33382/cejllpm.2020.04.06 